\title{
Assessment of the Surgical Staff Knowledge towards the Methods of Transmission of the Urinary Tract Infection at Selected Surgical Units, Saudi Arabia
}

\author{
Manal Amer ${ }^{1}$, Dr. Tamer Mohammed Ali Mahjari ${ }^{2}$, Dr. Anas Abdulkarim Alkhoutani ${ }^{3}$ \\ ${ }^{1}$ Assistant Professor, Cairo University, Al-Farabi College Jeddah \\ ${ }^{2}$ General Practitioner, King Abdulaziz Hospital, Makkah \\ ${ }^{3}$ General Practitioner, King Abdulaziz Hospital, Makkah
}

\begin{abstract}
Urinary tract infection (UTI) is one of the frequently widespread infections affecting the elderly patients. The aim of this article was to assess surgical staff knowledge towards the methods of transmission of the UTI. Looking forwards utilizing strategies for improving the management of UTI in elderly surgical inpatients.
\end{abstract}

Keywords: Urinary Tract Infection, Knowledge \& Surgical Units

\section{Methods}

A descriptive research design was utilized in the current research. A total of 150 surgical staff at selected surgical units was given a structured questionnaire On June, 2016. They were asked to indicate their knowledge towards the methods of transmission of the UTI. For each item concerning the knowledge towards the methods of transmission of the UTI the proportion of surgical staff perspectives towards measuring their level of knowledge about the methods of was calculated. Descriptive statistics like percentage was used to describe the findings using SPSS 20.

\section{Results}

The current research study objectives were to assess the surgical staff perspective toward methods of transmission of the UTI.Mean knowledge about of items pertaining to surgical staff towards the methods of transmission of the UTI within the study setting

was $(73.1 \%)$.

\section{Conclusions}

Concerning the surgical staff knowledge toward the methods of transmission of the UTI, contained by the study setting, the data findings showed that; there was a highest level of surgical staff knowledge towards the modes of transmission of urinary tract infection within the selected setting.

\section{Introduction}

Nowadays, infectious diseases is consider as one of the most common evidence based concepts to be investigated and involved in most of the surgical researches .Urinary tract infection (UTI) is one of the frequently widespread infections affecting the elderly patients. Nevertheless; UTI is over diagnosed and over treated in most of the health care setting all over the world. (Rao \& Patel ,2009).

According to McMurdo \&Gillespie, (2000), hospitalization put patient at associated risks, including risk of infection. Nosocomial infections, or hospital-associated infections, are estimated to occur in Five percent of all acute care hospitalizations, or two million cases per year. Hospitalassociated infections have been identified as one of the most serious patient safety issues in health care. Postponing urination, pregnancy, menopause, frequent intercourse, records on urinary infection during childhood are considered as predisposing factor to the infection. A quarter of women who reported urinary infection for the first time would be reinfected in less than 3 months. Early diagnose of urethral infection was considered very important to prevent relapse and indication of its complications such as rental failure, adhesions among pregnant women, abortion and early delivery

Woodford \& George, (2009), mentioned that infections that be converted into clinically obvious after forty eight hours of hospitalization are well thought-out hospitalassociated. Risks factors for hospital-associated infections are generally categorized into three areas: iatrogenic, organizational, or patient-related. Iatrogenic risk factors include invasive procedures like intubation, indwelling vascular lines, urine catheterization and antibiotic use and prophylaxis. Organizational risk factors include such things as contaminated air-conditioning systems, contaminated water systems, staffing, and physical layout of the facility as open beds close together). Examples of patient-related risk factors include severity of illness, immunosuppressant, and length of stay.

Attributable to increased risk of infection associated with urinary catheters, a number of practices have been evaluated in an attempt to reduce the incidence of urinary catheter- 


\section{International Journal of Science and Research (IJSR) \\ ISSN (Online): 2319-7064 \\ Index Copernicus Value (2015): 78.96 | Impact Factor (2015): 6.391}

related infections. These include alternative approaches to use of urinary catheters and antimicrobial urinary catheters. (UTI) is known as a common infection among women; in more than 95 percent of cases urinary infection is created by a certain group of bacteria; the major pathogen of urinary infection is E.coli bacteria, which is a normal bacterial flora in intestines. It seems that the reasons for increased prevalence of such infections among women are proximity of their urethral and anus, short length of urethral and warm and wet environment of perinea (Boscia,et al., 2012).

\section{Methods}

A descriptive research design was utilized in the current research. A total of 150 surgical staff of selected surgical units, Saudi Arabia, were given a structured questionnaire during June 2016.This number constitute, more than two third of the surgical staff of the time of data collection. All wards representing units concerning all the subspecialties' were consider as a setting for the current research. The surgical staff at each unit was contacted to discuss the importance of the research and the study protocol. An anonymous 20-items questionnaire was adopted from valid $\&$ reliable tool using the guidelines from a Taxonomy for
Augustine (1993). All questions had fixed answer categories.

The questionnaire was pilot-tested and dealt with the following topics: demographic data; data concerning knowledge towards the methods of transmission of the UTI. Descriptive statistics like percentage was used to describe the findings using SPSS 20. All categories data were analyzed using the Chi-squared test with or without Yates' correction; Statistical significance for all analyses was presumed for $\mathrm{P}$ at 0.05 .

\section{Results}

The current research study objectives were to assess the surgical staff perspective toward methods of transmission of the UTI. The Mean knowledge about of items pertaining to surgical staff towards the methods of transmission of the UTI within the study setting was (73.1\%).

Regarding the surgical staff knowledge toward the methods of transmission of the UTI, contained by the study setting, the data findings showed that; there was a highest level of surgical staff knowledge towards the modes of transmission of urinary tract infection within the selected setting.

Table 1: Frequency and Percentage of items pertaining to Surgical Staff towards the methods of transmission of the UTI

\begin{tabular}{|c|c|c|c|}
\hline $\begin{array}{l}\text { Sl. } \\
\text { No. }\end{array}$ & Knowledge of Items & $\begin{array}{l}\text { Frequency of correct } \\
\text { Response }\end{array}$ & $\begin{array}{c}\text { Percentage of } \\
\text { correct Responses }\end{array}$ \\
\hline 1 & $\begin{array}{l}\text { Hospital acquired infections are the result of self infection, cross infection \& environmental } \\
\text { infection }\end{array}$ & 20 & 40 \\
\hline 2 & The single most important measure for preventing HAI is hand washing & 43 & 86 \\
\hline 3 & The common causative organism of UTI is E. Coli & 37 & 74 \\
\hline 4 & HAI's are transmitted through body fluids, staff hands and reusable equipment & 45 & 90 \\
\hline 5 & Immunization is not a universal precaution & 44 & 88 \\
\hline 6 & Hemoglobin less than $11 \mathrm{gm} \%$ is not a sign of infection. & 48 & 96 \\
\hline 7 & Patients receiving immunosuppressive therapy are more susceptible to HAI & 44 & 88 \\
\hline 8 & In case of UTI, bacterial count of $10 \mathrm{CFU} / \mathrm{ml}$ of Urine c/s is significant & 22 & 44 \\
\hline 9 & Sterilization is a process of killing of microorganism including spores & 43 & 86 \\
\hline 10 & Glutehyde is to be changed every 28 days & 45 & 90 \\
\hline 11 & More than 15 CFU organisms are grown in an agar plate & 9 & 18 \\
\hline 12 & Sterile technique is not necessary for nose gastric feeding. & 41 & 82 \\
\hline 13 & The most important factor involved in hand washing is friction & 24 & 48 \\
\hline 14 & HAI is synonymous to nosocomial infection & 39 & 78 \\
\hline 15 & Moisture enhances the trans-mission of micro- organisms & 48 & 96 \\
\hline 16 & Boiling is a method of sterilization & 16 & 32 \\
\hline 17 & Chemical disinfection is the best method of sterilizing surgical instruments & 38 & 76 \\
\hline 18 & If a person doesn't show sign and symptoms of disease, he can't transfer a disease & 49 & 98 \\
\hline 19 & Alcohol is an effective disinfectant when rubbed in skin. & 39 & 78 \\
\hline 20 & UTI's are one of the most common forms of HAI & 37 & 74 \\
\hline
\end{tabular}

Mean knowledge about of items pertaining to Surgical Staff towards the methods of transmission of the UTI within the study setting was $(73.1 \%)$.

\section{Discussion}

The response rate to the current research was excellent, suggesting that this was an area of importance for surgical staff. In this research, more than two third of the surgical staff were replied that there was a high level of knowledge towards the transmission of urinary tract infection compared to a study conducted by Ciavarelli, Figlock \& Sengupta who studied the factors in aviation of the staff awareness in relation to methods of UTI transmission it revealed that the hospital staff reported $(46 \%)$ of the surgical staff in relation to organizational culture safety. Moreover, In Saudi Arabia, it was reported that there was a lack of skills in relation to utilization of the universal measures to prevent the transmission of UTI Urinary tract infection is a common infection among women and is followed by several complications. The aim of this study was determine the prevalence and factors influencing prevention of urinary tract infection based on health belief model. A crosssectional study was conducted among 166 female students in

\section{Volume 6 Issue 1, January 2017 www.ijsr.net}




\section{International Journal of Science and Research (IJSR) \\ ISSN (Online): 2319-7064}

Index Copernicus Value (2015): 78.96 | Impact Factor (2015): 6.391

Shadegan city, Iran; which was randomly selected with the proportional to size among different girls high school at Shadegan city for participation in this study. A structured questionnaire was applied for collecting data and data were analyzed by SPSS version 20 using bivariate correlations and logistic regression statistical tests. Almost $22.3 \%$ of the participants had history of experience urinary tract infection at last one in lifelong. The best predictor for urinary tract infection was perceived susceptibility with odds ratio estimate of 0.810 [95\% CI: $0.664,0.987]$. Based on our result, it seems that designing and implementation of educational programs to increase susceptibility about chance of getting urinary tract infection among the female students may be useful in order to prevent urinary tract infection.

Prevalence of UTI between women is high; in this regard, Eriksson et al in their study reported $29.6 \%$ of women were diagnosed as having UTI at least one. Furthermore, Sorto et al reported the UTI incidence among the women in their study was of $35.8 \%$. Studies showed the prevalence of UTI in different parts of the world, which made it necessary to determine and control its predisposing factors. Along this, personal health behaviors were considered as the major predisposing factors to relapse of urinary infection . Various factors are reflected in human behavior and it is vital to know the causality network to affect impressive factors on behavior, which has been investigated through years by behaviorists. Knowing effective factors on behavior showed to be operational in designing educational programs.

On the other hand, studies on designing education programs showed that the most effective educational programs were based on theory-based approaches rooted in behavior change patterns. The very first step to plan an education program is to choose a proper pattern or theory in health education while effective health education directly depends on the dominance on using best theories and proper approaches in each event. Several studies, also, reported that it was essential to focus on mental factors in health education comprehensive preventive programs as mediating and predicators of behavior; as the result health care providers should be aware of various effective factors on fulfilling preventive and health improving behaviors to be able to design and implement advantageous programs in the field . Hereof, it is worth to mention that health belief model (HBM) is an analytical behavior theory, which has been used in several studies on different fields of preventive behaviors.

\section{Conclusions}

The current research aimed to assess the surgical staff knowledge towards the methods of transmission of the UTI. Looking forwards utilizing strategies for improving the management of UTI in elderly surgical inpatients. The response rate to the current research was excellent, suggesting that this was an area of importance for surgical staff. In this research, more than two third of the surgical staff were replied that there was a high level of knowledge towards the transmission of urinary tract infection

The current study recommend utilization of continuous educational measures to enhance the surgical and other Health care providers to increase their knowledge towards the methods of transmission of the UTI. Furthermore applying performance feedback and increased availability of specialist equipments are imperative for improving management of UTIs in the elderly.

\section{Acknowledgements}

Thanks to all the interns helps in performing the current research

\section{References}

[1] Rao GG, Patel M. Urinary tract infection in hospitalized elderly patients in the United Kingdom: the importance of making an accurate diagnosis in the post broadspectrum antibiotic era. J Antimicrob Chemother 2009;63:5-6

[2] McMurdo MET, Gillespie ND. Urinary tract infection in old age: over-diagnosed and over-treated. Age Ageing 2000;29:297-8.

[3] Woodford HJ, George J. Diagnosis and management of urinary tract infection in hospitalized older people. J Am Geriatr Soc 2009;57:107-14.

[4] Boscia JA, Kobasa WD, Knight RA, et al. Lack of association between bacteriuria and symptoms in the elderly. Am J Med 2012;81:979-82.

[5] Scottish Intercollegiate Guidelines Network (SIGN). Management of suspected bacterial urinary tract infection in adults. Edinburgh: SIGN publication no. 88. July 2012. http://www.sign.ac.uk/guidelines/fulltext/88/index.html (accessed 20 January 2014).

[6] Scottish Intercollegiate Guidelines Network (SIGN). Algorithm: suspected UTI in older people, management of suspected bacterial urinary tract infection in adults. Edinburgh: SIGN publication no. 88. July 2012 http://www.sign.ac.uk/pdf/sign88_algorithm_older.pdf (accessed 20 January 2014.

[7] Levit K, Ryan K, Elixhauser A, et al. HCUP facts and figures: statistics on hospital-based care in the United States in 2005. Rockville, MD: Agency for Healthcare Research and Quality; 2007. Available at: www.hcupus.ahrq.gov/reports.jsp.

[8] Nguyen QV. Hospital acquired infections. Emedicine. 2004. [Accessed March 10, 2006]. http://www.emedicinecom/PED/topic1619.htm.

[9] Stone PW, Larson E, Kawar LN. A systematic audit of economic evidence linking nosocomial infections and infection control interventions: 1990-2000. Am J Infect Control. 2002;30(3):145-52. [PubMed].

[10] de Jonge E. Effects of selective decontamination of digestive tract on mortality and antibiotic resistance in the intensive-care unit. Curr Opin Crit Care. 2005;11(2):144-9. [PubMed].

[11] Centers for Disease Control and Prevention. Guidelines for preventing health-care associated pneumonia, 2003: recommendations of $\mathrm{CDC}$ and the Healthcare Infection Control Practices Advisory Committee. MMWR. 2004;53:1-35.

[12] Safdar N, Dezfulian C, Collard HR, et al. Clinical and economic consequences of ventilator-associated pneumonia: a systematic review. Crit Care Med. 2005;33:2184-93. [PubMed].

\section{Volume 6 Issue 1, January 2017}




\section{International Journal of Science and Research (IJSR) \\ ISSN (Online): 2319-7064 \\ Index Copernicus Value (2015): 78.96 | Impact Factor (2015): 6.391}

[13] Healthcare Infection Control Practices Advisory Committee and Hand-Hygiene Task Force, Society for Healthcare Epidemiology of America, Association for Professionals in Infection Control, Epidemiology, \& Infection Diseases Society of America. Guideline for hand hygiene in healthcare settings. J Am Coll Surg. 2004;198:121-7. [PubMed].

[14] Boyce JM, Pittet D. Guideline for hand hygiene in health-care settings: recommendations of the Healthcare Infection Control Practices Advisory Committee and the HICPAC/SHEA/APIC/IDSA Hand Hygiene Task Force. Infect Control Hos Epidemiol. 2002;23:S340. [PubMed]

[15] Kac G, Podglajen I, Gueneret M, et al. Microbiological evaluation of two hand hygiene procedures achieved by healthcare workers during routine patient care: a randomized study. J Hosp Infect. 2005;60:329. [PubMed].

[16] Thomas JA, McIntosh JM. Are incentive spirometry, intermittent positive pressure breathing, and deep breathing exercises effective in the prevention of postoperative pulmonary complications after upper abdominal surgery? A systematic overview and metaanalysis including commentary by Dean E with author response. Phys Ther. 1994;74(1):3-16. [PubMed].

[17] Overend TJ, Anderson CM, Lucy SD, et al. The effect of incentive spirometry on postoperative pulmonary complications: a systematic review. Chest. 2001;120:971-8. [PubMed].

[18] Chumillas S, Ponce JL, Delgado F, et al. Prevention of postoperative pulmonary complications through respiratory rehabilitation: a controlled clinical study. Arch Phys Med Rehabil. 1998;79:59. [PubMed].

[19] Hall JC, Tarala RA, Tapper J, et al. Prevention of respiratory complications after abdominal surgery: a randomised clinical trial. BMJ. 1996;312:14852. [PMC free article] [PubMed].

[20] Westerdahl E, Lindmark B, Eriksson T, et al. Deepbreathing exercises reduce atelectasis and improve pulmonary function after coronary artery bypass surgery. Chest. 2005;128:3482-8. [PubMed].

[21] Mackay MR, Ellis E, Johnston C. Randomised clinical trial of physiotherapy after open abdominal surgery in high risk patients. Aust J Physiother. 2005;51:1519. [PubMed].

[22] Craven DE, Kunches LM, Kilinsky V, et al. Risk factors for pneumonia and fatality in patients receiving continuous mechanical ventilation. Am Rev Respir Dis. 1986;133:792-6. [PubMed].

[23]Kollef MH. Ventilator-associated pneumonia. A multivariate analysis. JAMA. 1993;270:196570. [PubMed].

[24] Kollef MH. The identification of ICU-specific outcome predictors: a comparison of surgical, surgical, and cardiothoracic ICUs from a single institution. Heart Lung. 1995;24:60-6. [PubMed].

[25] Torres A, Serra-Batlles J, Ros E, et al. Pulmonary aspiration of gastric contents in patients receiving mechanical ventilation: The effect of body position. Ann Intern Med. 1992;116:540-3. [PubMed].

[26] Orozco-Levi M, Torres A, Ferrer M, et al. Semirecumbent position protects from pulmonary aspiration but not completely from gastroesophageal reflux in mechanically ventilated patients. Am J Respir Crit Care Med. 1995;152:1387-90. [PubMed] 